\title{
Biomass and physiology of papaya seedlings produced under leaf fertilization with Spirulina platensis
}

\section{Biomassa e fisiologia de mudas de mamoeiro produzidas sob adubação foliar com Spirulina platensis}

\author{
Railene Hérica Carlos ROCHA ${ }^{1}$; José Franciraldo de LIMA ${ }^{2}$; Tádria Cristiane de Sousa FURTUNATO3; \\ Fernando Julião de MEDEIROS JUNIOR ${ }^{4}$; Wellinghton Alves GUEDES ${ }^{5}$; Rosana Santos de ALMEIDA ${ }^{6}$ \\ ${ }^{1}$ Engenheira Agrônoma, Doutora em Fitotecnia, Professora da Universidade Federal de Campina Grande - Centro de Ciência \\ e Tecnologia Agroalimentar (UFCG/CCTA); raileneherica@ccta.ufcg.edu.br \\ ${ }^{2}$ Biotecnólogo, Universidade de São Paulo. Fazenda Tamanduá. Caixa Postal 65, CEP:58700-970. Patos, PB; \\ josefranciraldo@gmail.com \\ ${ }^{3}$ Engenheira agrônoma, Mestre em fitotecnia, Universidade Federal de Campina Grande - Centro de Ciência e Tecnologia \\ Agroalimentar (UFCG/CCTA); tadriacsf@hotmail.com \\ ${ }^{4}$ Agroecólogo, Mestre em Horticultura tropical, estudante de Pós-graduação (Doutorado em Ciência do Solo) Universidade \\ Federal da Paraíba; juliao.junior@hotmail.com \\ ${ }^{5}$ Autor para correspondência. Engenheiro agrônomo, estudante de Pós-graduação (Mestrado em Horticultura Tropical) \\ Universidade Federal de Campina Grande - Centro de Ciência e Tecnologia Agroalimentar (UFCG/CCTA); \\ wellinghton_guedes@hotmail.com \\ ${ }^{6}$ Agroecóloga, Mestre em Horticultura Tropical, Universidade Federal de Campina Grande - Centro de Ciência e Tecnologia \\ Agroalimentar (UFCG/CCTA); rosanaalmeidapb@yahoo.com.br
}

Recebido em: 28-09-2016; Aceito em: 23-02-2017

\begin{abstract}
The objective of this work was to evaluate the effect of different concentrations of Spirulina platensis on the production of papaya (Carica papaya L.) seedlings in a protected environment. A completely randomized design (CRD) with five treatments and four replications was used, with five plants in the experimental unit $(n=20)$. The treatments consisted of different concentrations of Spirufert $\Theta$, class " $\mathrm{A}$ " simple organic fertilizer, brand Tamanduá. Concentrations of $0,1,2,3$ and $4 \%$ were used, diluted in drinking water. Growth characteristics, biomass accumulation and physiological aspects of the seedlings were evaluated using analysis of variance and, in the cases of significant effect, regression analysis was performed. The use of Spirulina platensis (Spirufert $\circledast$ ) in low concentrations (1\%) provided an improvement in the productive performance of the papaya seedlings and influenced the variable water use efficiency $(A / E)$ in papaya seedlings.
\end{abstract}

Additional keywords: Carica papaya L.; microalgae; propagation; quality.

\section{Resumo}

O objetivo deste trabalho foi avaliar o efeito de diferentes concentrações de Spirulina platensis sob a produção de mudas de mamoeiro (Carica papaya L.), em ambiente protegido. Utilizou-se o delineamento inteiramente ao acaso (DIC) com cinco tratamentos e quatro repetições, sendo cinco plantas na unidade experimental $(n=20)$. Os tratamentos foram constituídos por diferentes concentrações de Spirufert@, fertilizante orgânico simples classe "A", marca Tamanduá. Utilizaram-se as concentrações de 0; 1; 2; 3 e 4\% do produto diluído em água potável. Avaliaram-se características de crescimento, acúmulo de biomassa e aspectos fisiológicos das mudas utilizando análise de variância e nos casos de efeito significativo, realizou-se análise de regressão. O uso de S. platensis em baixas concentrações (1\%) proporciona melhoria no desempenho produtivo das mudas de mamoeiro e influência na variável eficiência do uso da água $(E / A)$ das mudas de mamoeiro.

Palavras-chave adicionais: Carica papaya L.; microalga; propagação; qualidade.

\section{Introduction}

The papaya tree (Carica papaya L.) occupies a prominent place in Brazil, being cultivated in several regions of the country. The northeast is the main producing region of the fruit, with a production of $917.380 \mathrm{t}$, being highlighted the state of Bahia, the largest national producer, with a production of $683.474 \mathrm{t}$ (IBGE, 2012). Seminiferous propagation is predomi- nant in the papaya tree, therefore, it is more susceptible to segregation, which may contribute to a greater disuniformity of the plants in the production area (Cavalcante et al., 2014). To minimize this behavior, it is important to acquire seeds of good quality and of known origin, whose genetic material of the parents meets the characters required by the fruit market.

The cultivation of papaya in all its stages, from the production of seedlings to the processing at harv- 
est and postharvest stages, should prioritize techniques that favor improvements in handling, with environmental and food safety to the consumer. According to Costa et al. (2010), the stage of seedling production is fundamental to the success of the orchard, as the literature indicates that seedling quality is related to the yield potential of adult plants. In this sense, natural products have been a priority in cultivation, especially in organic agriculture. The use of microalgae appears as an innovation and a promising alternative for the production and processing stages (Moreira, 2014; Silva, 2015), since nutrient applications are used when using commercial substrates in the production of seedlings (Serrano et al., 2010).

The microalgae exist in a number of classes and are distinguished mainly by their pigmentation, life cycle and cellular structure, with Spirulina platensis being of the main commercialized species (Schmitz et al., 2012).

According to Derner et al., (2006), microalgae biomass can be used in the soil as fertilizer. Another option for its use is the manufacture of foliar fertilizer or biostimulant, where the growth and development of plants are promoted through the auxin present in the biomass (Limberger \& Gheller, 2012).

In this aspect, the present study aimed to evaluate the biomass and physiology of papaya seedlings produced with the foliar application of Spirulina platensis (Spirufert $\AA$, class "A" simple organic fertilizer, brand Tamanduá).

\section{Material and methods}

The experiment was conducted in a greenhouse, using 'Formosa' papaya seedlings, from September to December 2014. The geographic coordinates are $6^{\circ} 46^{\prime} 13^{\prime \prime}$ south latitude and $37^{\circ} 48^{\prime} 06^{\prime \prime}$ west longitude from Greenwich, with a mean altitude of $184 \mathrm{~m}$; and the variations in the greenhouse comprise a minimum temperature of $22^{\circ} \mathrm{C}$, mean of $30{ }^{\circ} \mathrm{C}$ and maximum of $38{ }^{\circ} \mathrm{C}$, in addition to a minimum relative humidity of $20 \%$, mean of $45 \%$ and maximum of $80 \%$ for the period (Paiva et al., 2015).

The design was completely randomized, with five treatments and four replications, with five plants in the experimental unit $(n=20)$. The treatments consisted of different concentrations of Spirufert $\circledast$, class "A" simple organic fertilizer, brand Tamanduá. Concentrations of $0,1,2,3$ and $4 \%$ were used (Table 1), diluted in drinking water, followed by filtration in a domestic sieve and transfer to a $900 \mathrm{~mL}$ hand sprayer, for further application.

Table 1 - Chemical and physical constitution of the simple organic fertilizer class "A", brand Tamanduá (Spirufert@).

\begin{tabular}{|c|c|c|c|c|c|c|c|c|c|c|c|c|}
\hline $\mathrm{pH}$ & EC & $\mathrm{N}$ & $P$ & $\mathrm{~K}$ & $\mathrm{Ca}$ & $\mathrm{Mg}$ & $S$ & $\mathrm{Na}$ & \multirow{2}{*}{\multicolumn{4}{|c|}{ - }} \\
\hline - & $\left(\mathrm{dS} \mathrm{m}^{-1}\right)$ & (\%) & $\left(\mathrm{mg} \mathrm{dm}^{-3}\right)$ & $\cdots$ & $-\cdots($ & \multicolumn{3}{|c|}{$\left(\mathrm{cmol}_{\mathrm{c}} \mathrm{dm}^{-3}\right)$} & & & & \\
\hline 3.7 & 1.04 & 4.40 & 0.82 & 0.68 & 0.16 & 0.23 & 0.45 & 0.20 & 25.95 & 94.70 & 5.30 & 76.40 \\
\hline $\mathrm{C} / \mathrm{N}$ & $\begin{array}{r}\mathrm{CE} \\
\left(\mathrm{cmol}_{\mathrm{c}}\right.\end{array}$ & $\left(\mathrm{m}^{-3}\right)$ & $\begin{array}{l}\text { Relation } \\
\text { CEC/OC }\end{array}$ & $\begin{array}{l}\text { Sali } \\
\text { ind } \\
(\%\end{array}$ & & $\mathrm{Fe}$ & $\mathrm{Mn}$ & $\mathrm{Cu}$ & & Zn & B & Co \\
\hline $5 / 1$ & 1.3 & & 5.0 & 2.9 & & 280.0 & 15.0 & 10.0 & 6 & 0 & 245.0 & 15.0 \\
\hline
\end{tabular}

Source: Unithal Laboratory. Sample results in weight / weight basis and dry matter. EC - Electrical conductivity; N - nitrogen; P phosphorus; K - potassium; Ca - calcium; Mg - magnesium; S - sulfur; Na - sodium; OC - organic carbon; OM - organic matter; $\mathrm{H}$ - humidity; $\mathrm{C} / \mathrm{N}$ - carbon and nitrogen ratio; CEC - cation exchange capacity; Fe - iron; Mn - manganese; Cu - copper; Zn zinc; $\mathrm{B}$ - boron, and Co - cobalt.

In the application, the volume used was determined by the runoff point of the syrup under the plants. The applications started at 30 days after sowing (DAS), being performed in the late afternoon, three times a week, repeating the practice for three consecutive weeks.

The substrate for the production of seedlings was composed of soil and Bokashi, in the ratio of 3:1 (Table 2). At sowing, three seeds of 'Formosa' papaya, brand Feltrin, were deposited in a polyethylene bag, with dimensions of $15 \times 25 \mathrm{~cm}$. Thirty days after the emergence, the thinning of seedlings was performed, remaining only the most vigorous. Irrigations were carried out daily, keeping the plants at field capacity, using a watering can.

Periodically, at $30,48,52$ and 60 DAS, the following evaluations were performed: number of leaves (NL), by direct counting; stem diameter (SD), with the use of a digital caliper; and seedling height $(\mathrm{H})$, with a graduated ruler. Physiological and biomass evaluations were carried out at 65 days after sowing

In the physiological analyses, the gas exchanges of plants were determined using the infrared gas analyzer (IRGA) (LCpro+) with constant light of $1,200 \mu \mathrm{mol}$ photons $\mathrm{m}^{-2} \mathrm{~s}^{-1}$, obtaining the following variables: $\mathrm{CO}_{2}$ assimilation rate $\left(\mu \mathrm{mol} \mathrm{m} \mathrm{m}^{-2} \mathrm{~s}^{-1}\right)$, transpiration (mol $\left.\mathrm{H}_{2} \mathrm{O} \mathrm{m}^{-2} \mathrm{~s}^{-1}\right)$, stomatal conductance $\left(\mathrm{mol} \mathrm{H}_{2} \mathrm{O} \mathrm{m}^{-2} \mathrm{~s}^{-1}\right)$ and internal $\mathrm{CO}_{2}$ concentration; the intermediate leaves were chosen in order not to underestimate the values, being selected five plants per treatment. Based on these data, the water use

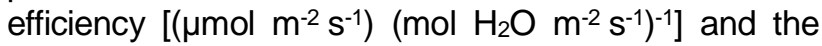
instantaneous efficiency of carboxylation $\Phi \mathrm{C}$ were quantified (Neves et al., 2002; Konrad et al., 2005; Ribeiro, 2006). 
Table 2 - Chemical analysis of the substrate used for production of papaya seedlings before and after the use of Spirufert田.

\begin{tabular}{|c|c|c|c|c|c|c|c|c|c|c|}
\hline \multirow{3}{*}{ Substrate } & MII & EC & $\mathrm{Ca}$ & $\mathrm{Mg}$ & $\overline{A l}$ & $\mathrm{Al}+\mathrm{H}$ & $\mathrm{Na}$ & $\bar{K}$ & $P$ & $\mathrm{OM}$ \\
\hline & $\mathrm{CaCl}_{2}$ & & & & & $\left.\mathrm{dm}^{-3}\right)$ & & & ---( & 1 \\
\hline & \multicolumn{10}{|c|}{ Before using Spirulina platensis (Spirufert®) } \\
\hline \multirow[t]{2}{*}{ Soil + Bokashi (SB) } & 6.1 & 350.6 & 5.8 & 5.4 & 0.40 & 5.4 & 0.49 & 0.6 & 5.3 & 0.72 \\
\hline & \multicolumn{10}{|c|}{ After using Spirulina platensis (Spirufert®) } \\
\hline SB+ Spirufe & 6.3 & 184.1 & 5.4 & 4.1 & 0.0 & 4.1 & 0.63 & 0.5 & 1.6 & 0.63 \\
\hline SB+ Spirufert 1\% & 6.3 & 211.3 & 6.0 & 4.0 & 0.0 & 5.1 & 0.48 & 0.3 & 5.6 & 0.84 \\
\hline $\mathrm{SB}+$ Spirufert 2\% & 6.5 & 244.1 & 5.7 & 4.2 & 0.0 & 2.6 & 0.73 & 0.5 & 5.7 & 0.79 \\
\hline SB+ Spirufert 3\% & 6.4 & 210.6 & 5.4 & 5.2 & 0.0 & 3.4 & 0.63 & 0.4 & 5.7 & 0.27 \\
\hline SB+ Spirufert 4\% & 6.4 & 216.2 & 5.2 & 5.8 & 0.0 & 4.1 & 0.63 & 0.5 & 5.8 & 0.16 \\
\hline
\end{tabular}

Source: Analyses carried out in the soil laboratory of the Science and Technology Center Agrifood, UFCG. EC - Electrical conductivity; $\mathrm{Ca}$ - calcium; Mg - Magnesium; Al - Aluminum; Al + H - Acidity potential; $\mathrm{Na}$ - Sodium; K - Potassium; P Phosphorus; OM - organic matter.

For biomass analyses, it were determined the fresh mass of the root system (FMR), fresh mass of shoots (FMS), total fresh mass (TFM), dry mass of root (DMR), dry mass of shoots (DMS) and total dry mass (TDM). The dry mass is determined by drying the parts of the plant in a forced air circulation oven at 65 ${ }^{\circ} \mathrm{C}$, until constant weight. The total, fresh and dry masses were obtained by the sum of the parts represented by the root system and shoots, respectively.

The variables were analyzed by analysis of variance, by $\mathrm{F}$ test ( 1 and $5 \%$ probability) and, in cases of significant effect, regression analysis was performed using the statistical software SISVAR (Ferreira, 2011). The choice of regression was made given the better adjustment on the basis of coefficient of determination $\left(R^{2}\right)$ and taking into account a probable biological explanation.

\section{Results and discussion}

According to the interpretation of the growth data, there was no significant difference in the interaction between the Spirufert ${ }^{\circledR}$ concentrations and the age of seedlings for the variables number of leaves $(\mathrm{NL})$, stem diameter (SD) and seedling height $(\mathrm{H})$. There was also no significant difference in the Spirufert $(B$ concentrations, when analyzed alone, in these three variables studied (Table 3).

Table 3 - Summary of the analysis of variance for leaf number (NL), stem diameter (SD) and height (H) seedlings due to different concentrations of Spirufert $\circledast$ and age of seedlings.

\begin{tabular}{|c|c|c|c|c|}
\hline \multirow{2}{*}{ Causes of variation } & \multirow{2}{*}{ (1) DF } & \multicolumn{3}{|c|}{ Mean Square } \\
\hline & & $\mathrm{NL}$ & SD & $\mathrm{H}$ \\
\hline Spirufert® (SP) & 4 & $0.353^{\mathrm{ns}}$ & $2.408^{\mathrm{ns}}$ & $4.306^{\mathrm{ns}}$ \\
\hline Error (SP) & 15 & 1.809 & 1.097 & 9.708 \\
\hline AGE (A) & 3 & $69.556^{* *}$ & $67.332^{\star *}$ & $485.915^{\star \star}$ \\
\hline$S P \times A$ & 12 & $0.481 \mathrm{~ns}$ & $1.492 \mathrm{~ns}$ & $2.785^{\text {ns }}$ \\
\hline Error (A) & 45 & 4.456 & 3.594 & 28.583 \\
\hline (2) $\mathrm{CV} \%$ (SP) & & 6.64 & 30.08 & 16.41 \\
\hline $\mathrm{CV} \%(\mathrm{SP} \times \mathrm{A})$ & & 23.56 & 36.75 & 42.28 \\
\hline Mean & & 8.96 & 5.15 & 12.64 \\
\hline
\end{tabular}

(1) Degrees of freedom; (2) Coefficient of variation; ${ }^{* *}$ - Significant at $1 \%$ probability by the $\mathrm{F}$ test; * - Significant at $5 \%$ probability by the $\mathrm{F}$ test; $\mathrm{ns}$ - not significant.

Although the leaf product applied did not show a significant effect, NL increased gradually with the increase in the age of seedlings, with a higher NL in the seedlings at 60 DAS (Figure 1).

Similar behavior regarding the use of microalgae in the production of seedlings was observed by other authors. Guimarães et al. (2012) did not find a significant difference in the variable number of leaves when evaluating different concentrations of Ascophyllum nodosum, applied foliarly in papaya seedlings. Garcia et al. (2014), evaluating the effect of the extract of the microalgae Ascophyllum nodosum on cashew seedlings found that the extract concentrations did not influence the number of leaves either.
A study carried out with Solanum melongena demonstrated divergent results, where the foliar application of Marginatum stoechospermum shows that the concentration of $1.5 \%$ provides increased growth, biochemistry and yield parameters in eggplant due to the presence of elements such as macronutrients and micronutrients, growth hormones, oligoelements and vitamins (Ramya et al., 2015).

In agreement with the increase in the NL, with the advancement of age of seedlings, there was an increase in the SD, which corresponded to $62.5 \%$ from 30 DAS to 60 DAS (Figure 2). Similar behavior was observed by Garcia et al. (2014), who did not obtain a 
significant difference for stem diameter in cashew seedlings treated with Ascophyllum nodosum. According to Sá et al. (2013), the diameter is one of the characteristics that expresses a higher quality and resistance of the seedling to be introduced in the field.

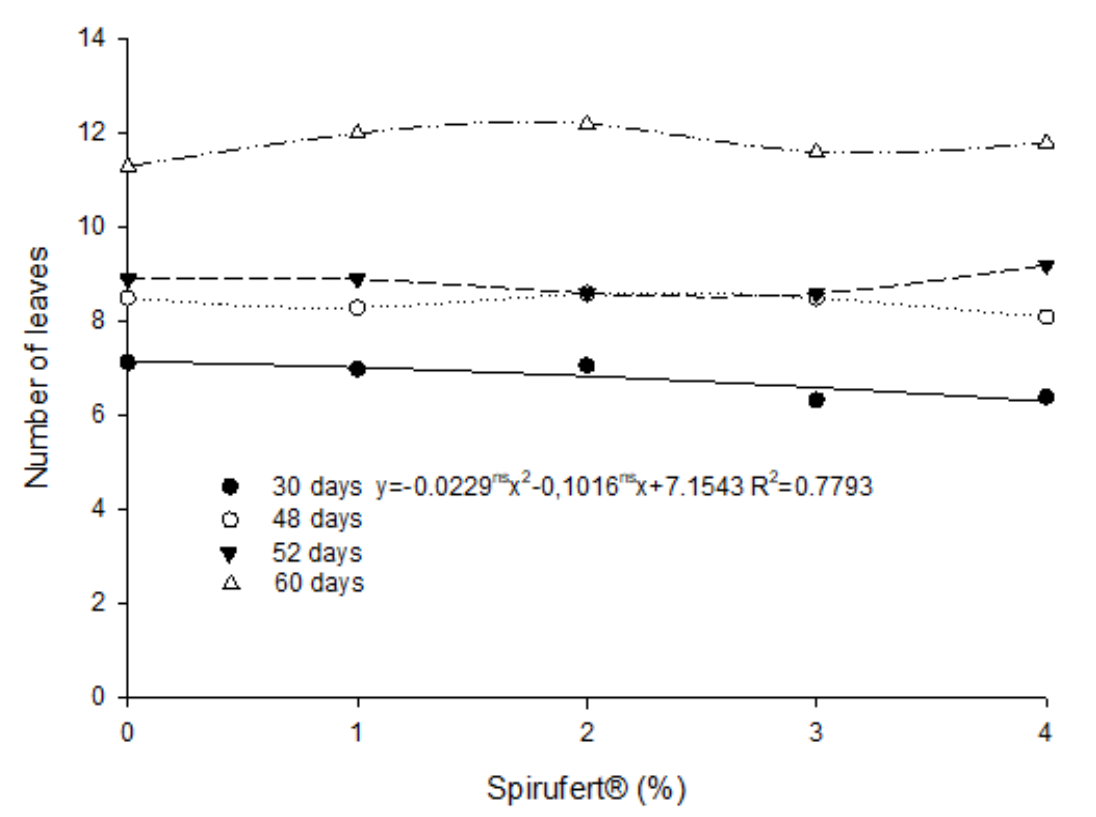

Figure 1 - Number of leaves as a function of the age of papaya seedlings and concentrations of Spirufert@.

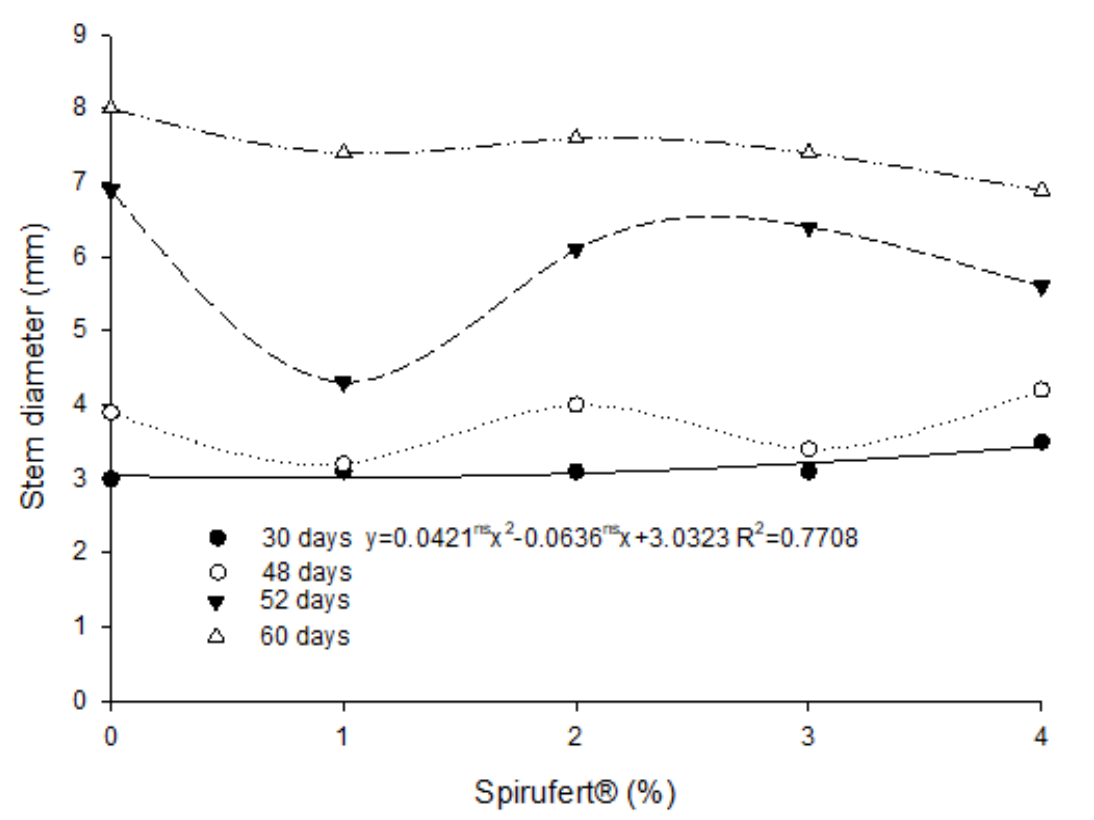

Figure 2 - Stem diameter as a function of the age of papaya seedlings and concentrations of Spirufert@.

In agreement with NL and SD, seedling height had a similar behavior. This $\mathrm{H}$ doubled in values from 30 DAS to 60 DAS (Figure 3). Garcia et al. (2014) and Silva et al. (2012), evaluating the effect of the extract of the microalgae Ascophyllum nodosum on cashew and cabbage (Brassica oleracea L.) seedlings, respectively, found that the concentrations of the extract did not influence the variable seedling height at the concentrations tested. Divergent results were obtained by Garcia-Gonzalez \& Sommerfeld (2016), who studied the use of a biofertilizer based on the microalgae Dimorphus acutodesmus, where the foliar application of $3.75 \mathrm{~g}$ yielded a higher plant height in tomato (Solanum lycopersicum). 


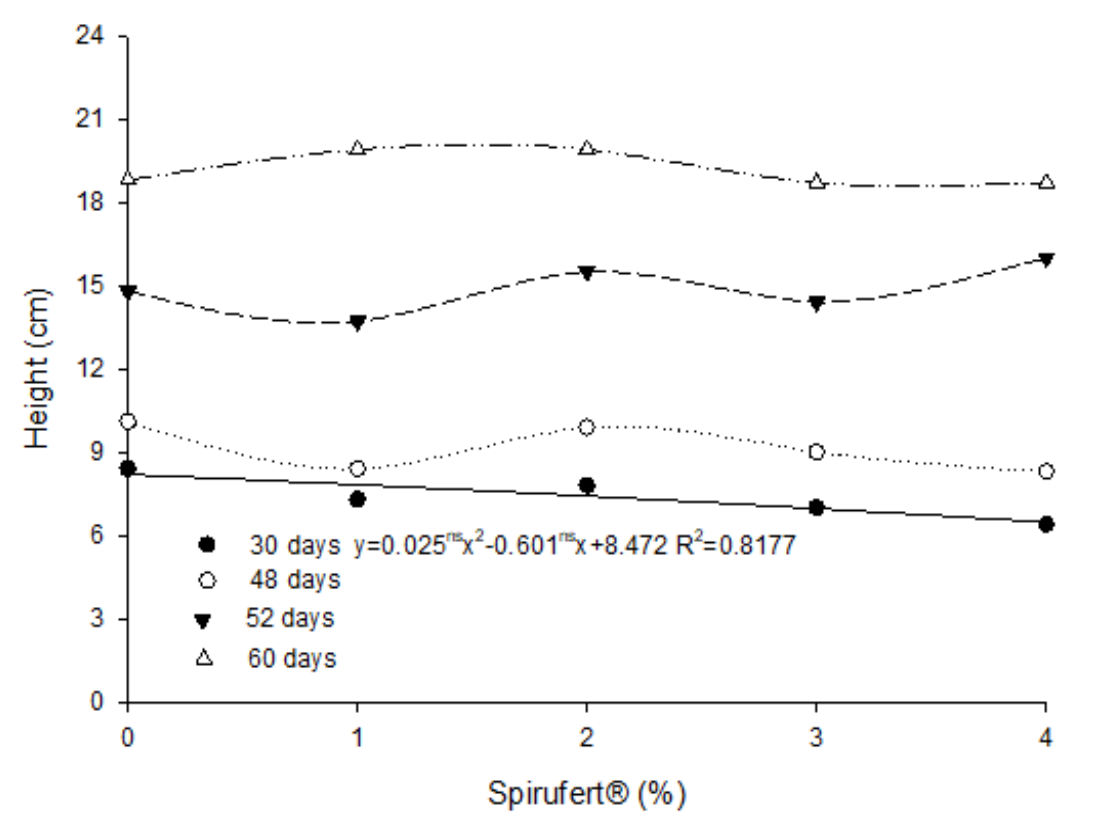

Figure 3 - Height as a function of the age of papaya seedlings and concentrations of Spirufert@i.

Regarding the physiological variables, no significant effect was observed in the Spirufert@ ${ }^{\circ}$ concentrations for leaf net photosynthesis $(A)$, transpiration $(\mathrm{E})$, stomatal conductance (Gs), internal $\mathrm{CO}_{2}$ concen- tration (Ci) and instantaneous efficiency of carboxylation $(\mathrm{A} / \mathrm{Ci})$. Only for the variable water use efficiency $(E / A)$ there was a significant effect at a $1 \%$ probability level (Table 4).

Table 4 - Summary of the analysis of variance for $\mathrm{CO}_{2}$ assimilation rate $(A)$, transpiration $(E)$, stomatal conductance (Gs), internal $\mathrm{CO}_{2}$ concentration (Ci), efficiency of water use $(\mathrm{E} / \mathrm{A})$ and the instantaneous efficiency of carboxylation $(\mathrm{A} / \mathrm{Ci})$ for concentrations of Spirufert $\AA$ in the production of papaya seedlings 65 days old after sowing.

\begin{tabular}{|c|c|c|c|c|c|c|c|}
\hline \multirow{2}{*}{$\begin{array}{l}\text { Causes of } \\
\text { variation }\end{array}$} & \multirow{2}{*}{ (1)DF } & \multicolumn{6}{|c|}{ Mean Square } \\
\hline & & $A$ & $E$ & Gs & $\mathrm{Ci}$ & $E / A$ & $\mathrm{~A} / \mathrm{Ci}$ \\
\hline Spirufert@ & 4 & 13.724 ns & $0.038 \mathrm{~ns}$ & $0.007^{\mathrm{ns}}$ & $875.46 \mathrm{~ns}$ & $1.730^{* *}$ & $0.00024 \mathrm{~ns}$ \\
\hline Error & 20 & 7.061 & 0.516 & 0.003 & 185.72 & 0.095 & 0.00017 \\
\hline (2) CV (\%) & & 23.05 & 21.68 & 34.41 & 6.24 & 8.84 & 24.40 \\
\hline Mean & & 11.53 & 3.31 & 0.176 & 218.48 & 3.48 & 0.0528 \\
\hline
\end{tabular}

(1) Degrees of freedom; (2) Coefficient of variation; ${ }^{* *}$ Significant at $1 \%$ probability by the $\mathrm{F}$ test; ns - not significant.

The $\mathrm{E} / \mathrm{A}$ decreased with increasing concentrations of Spirufert ${ }^{\circledR}$ (Figure 4). In this sense, the plants had a smaller capacity to limit the loss of water, while absorbing carbon dioxide. As papaya is a $\mathrm{C}_{3}$ plant, there was a limitation in the assimilation of $\mathrm{CO}_{2}$ in situations of nutritional complementation.

No significant effect was detected for the variables fresh mass of shoots (FMS), dry mass of shoots (DMS), fresh mass of roots (FMR), dry mass of roots (DMR), total fresh mass (TFM) and total dry mass (TDM) (Table 5).

The use of Spirufert ${ }^{\circledR}$ in lettuce production also did not have a significant effect on the variables, number of leaves, fresh mass of shoot, plant height, crown diameter, dry mass, root length, dry mass of the root, total fresh plant mass and total dry mass of the plant of lettuce (Silva, 2015).
The dry mass of roots and shoots presented similar behavior to the fresh mass (Figure 5 and 6). Garcia et al. (2014) verified that the increase of the doses of the microalgae extract resulted in a reduction of the dry mass of the root system, and from the $2 \mathrm{ml} \mathrm{L}^{-1}$ dose of the extract, there was a decrease of approximately $13.28 \%$. Almeida et al. (2014) observed similar results in their work for the dry mass of shoots, where also no effects of the doses of the algae extract were observed in acerola rootstock.

In contrast, Guimarães et al. (2012) verified a linear increase in the total dry mass of papaya seedlings as a function of the increase in the concentration of the product based on algae extract (Raiza®), in the order of $0.59 \mathrm{~g} \mathrm{plant}^{-1}$ per unit increase in the concentration thereof, resulting in a concentration of $2 \%$ in a total of $76.8 \%$ compared to the control. 


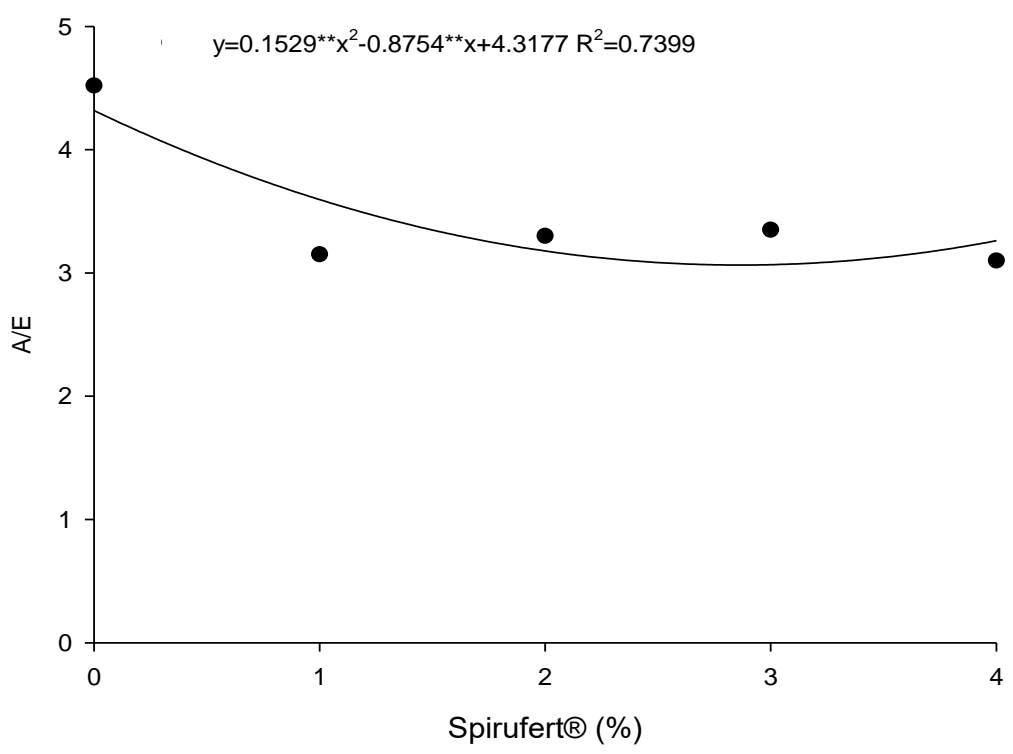

Figure 4 - Efficiency in water use $(E / A)\left(\mu \mathrm{mol} \mathrm{m}^{-2} \mathrm{~s}^{-1}\right)$ in papaya seedlings due to concentrations of Spirufert $\Theta, 65$ days old after sowing.

Table 5 - Summary of the analysis of variance for fresh mass of shoot (FMS), dry mass of shoot (DMS), fresh mass of root (FMR), dry mass of root (DMR), total fresh mass (TFM) and total dry mass (TDM) due to concentrations of Spirufert $\AA^{\circledR}$ in the production of papaya seedlings 65 days old after sowing.

\begin{tabular}{lccccccc}
\hline Causes of & \multirow{2}{*}{ DF } & \multicolumn{7}{c}{ Mean Square } \\
\cline { 3 - 7 } variation & \multicolumn{1}{c}{ FMS } & DMS & FMR & DMR & TFM & TDM \\
\hline Spirufert $(\AA)$ & 4 & $5.518^{\text {ns }}$ & $0.265^{\text {ns }}$ & $2.267^{\text {ns }}$ & $0.018^{\text {ns }}$ & $9.941^{\text {ns }}$ & $0.055^{\text {ns }}$ \\
Error & 20 & 3.090 & 0.271 & 0.483 & 0.007 & 5.498 & 0.299 \\
\hline Mean & & 11.36 & 1.79 & 6.70 & 18.63 & 15.09 & 2.246 \\
CV $(\%)$ & & 15.46 & 29.05 & 18.75 & 0.474 & 15.53 & 24.35 \\
\hline
\end{tabular}

(1) Degrees of freedom; (2) Coefficient of variation; ns - not significant.

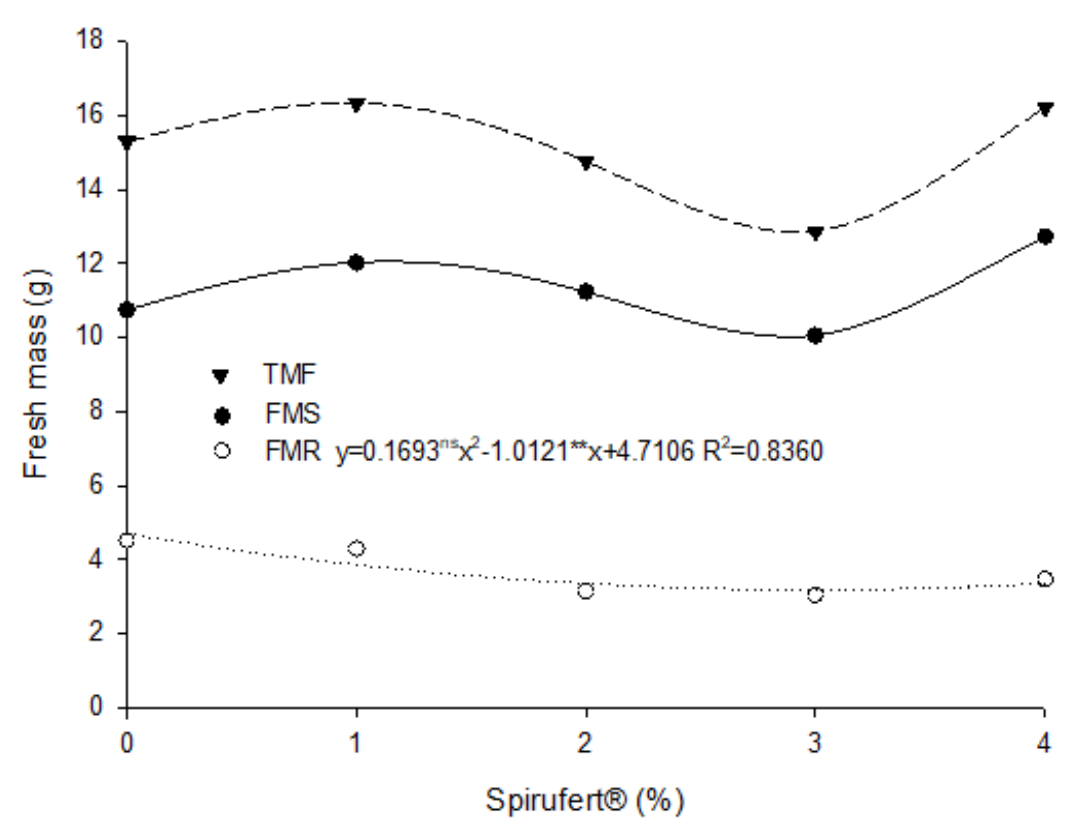

Figure 5 - Total fresh mass (TFM), fresh mass of root (FMR) and fresh mass of shoot (FMS) of papaya seedlings due to different concentrations of Spirufert@. 


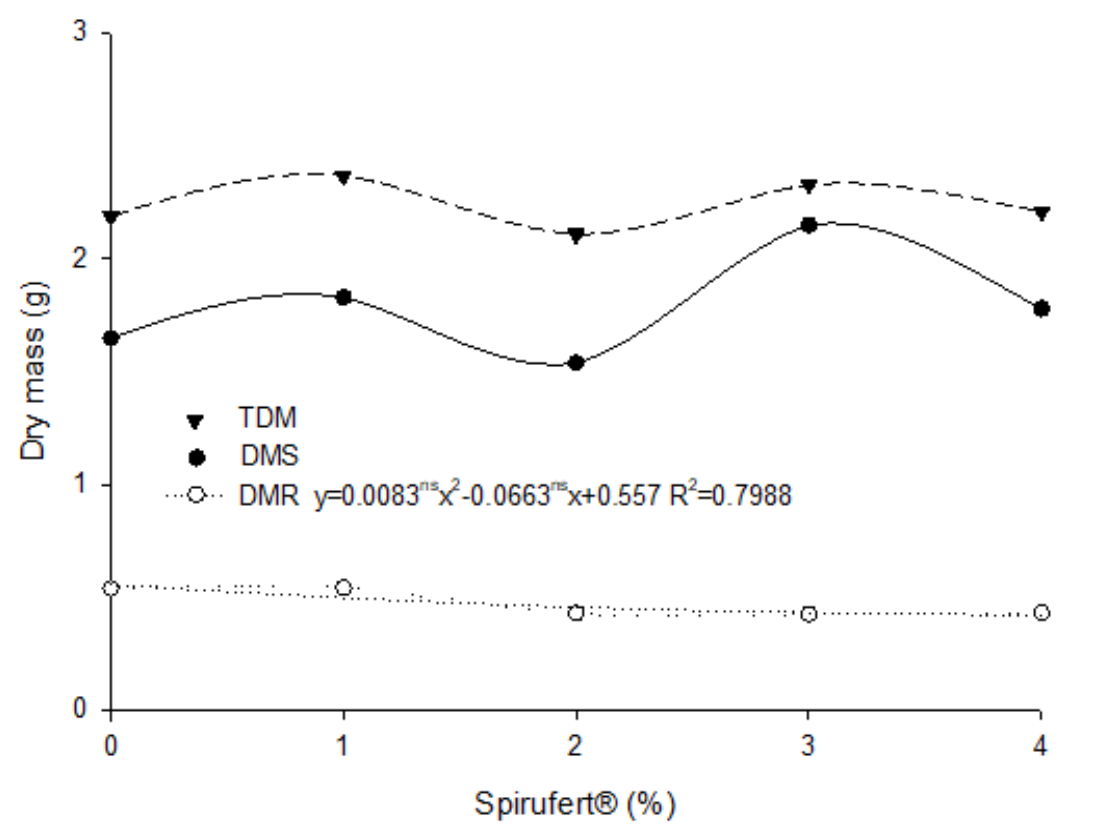

Figure 6 - Dry mass of root (DMR), dry mass of shoot (DMS) and total dry matter (TDM) of papaya seedlings for different concentrations of Spirufert@i.

\section{Conclusions}

The use of Spirulina platensis (Spirufert@) in low concentrations (1\%) provided an improvement in the productive performance of the papaya seedlings and influenced the variable water use efficiency $(A / E)$.

\section{References}

Almeida JPN, Dantas LLGR, Arrais ÍG, Tosta MS, Mendonça V (2014) Fungo micorrízico arbuscular e extrato de algas no crescimento inicial de porta-enxerto de aceroleira. Revista Ciências Agrárias 57(1):22-28. Disponível em: <http://dx.doi.org/10.4322/rca.2013.061>.

Cavalcante JA, Pereira NAE, Nobre RG, Lopes KP, Marques KM (2014) Qualidade fisiológica de sementes de mamão submetidas a diferentes métodos de remoção da sarcotesta. Revista Verde 9(2):285-290. Disponível em: <http://dx.doi.org/10.18378/rvads.v9i2.2887>.

Costa E, Leal PAM, Santos LCR, Vieira LCR (2010) Crescimento de mudas de mamoeiro conduzidas em diferentes ambientes protegidos, recipientes e substratos na região de Aquidauana, Estado do Mato Grosso do Sul. Acta Scientiarum Agronomy 32(3):463470. Disponível em: <http://dx.doi.org/10.4025/actasciagron.v32i3.4449>.

Derner RB, Ohse DS, Villela M, Carvalho SM, Fett R (2006) Microalgas, produtos e aplicações. Ciência Rural 36(6):1959-1967. Disponível em: $<$ http://www.scielo.br/pdf/cr/v36n6/a50v36n6.pdf>.
Ferreira DF (2011) Sisvar: um sistema computacional de análise estatística. Ciência e Agrotecnologia 35(6):1039-1042. Disponível em: <http://dx.doi.org/10.1590/S1413-70542011000600001>

Garcia KGV, Silva CP, Cunha CSM, Nascimento CDV, Tosta MS (2014) Extrato da alga Ascophyllum nodosum (L.) no desenvolvimento de porta-enxertos de cajueiro. Enciclopédia biosfera, 10(18):1707. Disponível em: <http://www.conhecer.org.br/enciclop/2014a/AGRARIA S/extrato\%20da\%20alga.pdf>.

Garcia-Gonzalez J, Sommerfeld M (2016) Biofertilizer and biostimulant properties of the microalgae Acutodesmus dimorphus. Jounal of Applied Phycology 28(2):1051-1061. Disponível em: http://link.springer.com/article/10.1007/s10811-0150625-2

Guimarães IP, Benedito CP, Cardoso EA, Pereira FECB, Oliveira, DM (2012) Avaliação do efeito do uso do extrato de alga (Raiza $\AA_{\text {) }}$ no desenvolvimento de mudas de mamão. Enciclopédia biosfera 8(15):312$320 . \quad$ Disponível em: <http://www.conhecer.org.br/enciclop/2012b/ciencias\% 20agrarias/avaliacao\%20do\%20efeito.pdf>.

IBGE - Instituto Brasileiro de Geografia e Estatística (2012) Produção agrícola municipal. Disponível em: <http://www.ibge.gov.br/home/estatistica/pesquisas/pe squisa_resultados.php?id_pesquisa $=44>$. Acesso em 05 mar. 2016.

Konrad MLF, Silva JAB, Furlani PR, Machado EC (2005) Trocas gasosas e fluorescência da clorofila em seis cultivares de cafeeiro sob estresse de alumínio. Bragantia 64(3):339-347. Disponível em: <http://www.scielo.br/pdf/brag/v64n3/26427.pdf>. 
Limberger PA, Gheller JA (2012) Efeito da aplicação foliar de extrato de algas, aminoácidos e nutrientes via foliar na produtividade e qualidade de alface crespa. Revista Brasileira de Energias Renováveis 1:148-161. Disponível em: $<$ file:///C:/Users/Wellinghton/Downloads/Artigo_12_201 $1 \% 20(2) \cdot$.pdf $>$.

Moreira IS (2014) Qualidade de romã 'Molar' submetida a temperaturas de armazenamento e biofilmes comestíveis. UFCG (Dissertação de mestrado em Sistemas Agroindústrias).

Neves LLM, Siqueira DL, Cecon PR, Martinez CA, Salomão LCC (2002) Crescimento, trocas gasosas e potencial osmótico da bananeira "Prata" submetida a diferentes doses de sódio e cálcio em solução nutritiva. Revista Brasileira de Fruticultura 24(2):524-529. Disponível em: <http://dx.doi.org/10.1590/S010029452002000200049>.

Paiva EP, Rocha RHC, Sousa FA, Nobre RG, Guedes WA, Moreira IS, Sá FVS (2015) Crescimento e fisiologia de mudas de romãzeira cv. Wonderful propagadas por enxertia. Revista Brasileira de Ciências Agrárias 10(1):117-122. Disponível em: $<10.5039$ /agraria.v10i1a5170>.

Ramya SS, Vijayanand N, Rathinavel S (2015) Foliar application of liquid biofertilizer of brown alga Stoechospermum marginatum on growth, biochemical and yield of Solanum melongena. International Journal of Recycling of Organic Waste in Agriculture 4:167173. Disponível em: $<$ http://link.springer.com/article/10.1007/s40093-0150096-0>.
Ribeiro RV (2006) Variação sazonal da fotossíntese e relações hídricas de laranjeira "Valência". USP (Tese de doutorado em agronomia).

Sá FV, Brito MEB, Melo AS, Antônio Neto $P$, Fernandes PD, Ferreira IB (2013) Produção de mudas de mamoeiro irrigadas com água salina. Revista Brasileira de Engenharia Agrícola e Ambiental 17(10):1047-1054. Disponível em: <http://www.agriambi.com.br/revista/v17n10/v17n10a0 4.pdf $>$.

Schmitz R, Magro CD, Colla LM (2012) Aplicações ambientais de microalgas. Revista Ciências Exatas Aplicadas e Tecnológicas 4(1):48-60. Disponível em: $<$ http://www.agriambi.com.br/revista/v17n10/v17n10a0 4.pdf $>$.

Serrano LA, Cattaneo LF, Ferreguetti GA (2010) Adubo de liberação lenta na produção de mudas em mamoeiro. Revista Brasileira Fruticultura 32(3):874883. Disponível em: <http://www.scielo.br/pdf/rbf/v32n3/aop09010>.

Silva CP, Garcia KGV, Silva RM, Oliveira LAA, Tosta MS (2012) Desenvolvimento inicial de mudas de couve-folha em função do uso de extrato de alga (Ascophyllum nodosum). Revista Verde 6(1):7-11. Disponível em: <http://www.gvaa.com.br/revista/index.php/RVADS/arti cle/view/1160/1064>.

Silva DSO (2015) Produção, fisiologia e qualidade póscolheita da alface 'Elba' sob adubação foliar com Spirulina platensis. UFCG (Dissertação de mestrado em Horticultura Tropical). 